UDC 81'32

https://doi.org/10.31548/philolog2020.03.016

\title{
MONOMIALS AS SET TERM CLUSTERS IN TERMINOLOGIES
}

\author{
O. I. CHAIKA, PhD in Philology, Associate Professor, \\ National University of Life and Environmental Sciences of Ukraine \\ E-mail: oxana.chaika@yahoo.es \\ https://orcid.org/0000-0002-4317-9456
}

\begin{abstract}
The present paper tightly links to the earlier introduced idea of monomials and polynomials as substitutes of the term in linguistics when applicable to languages for specific purposes, or terminologies. The classification by Oksana Chaika (2019) of monomials and polynomials stresses out the similarities between terms and interrelation of the terms in an algebraic expression (its terms/components and operations) in mathematics and terms / components of the term and interrelation of the terms in the term, which is a terminological set expression in a language for specific purpose. Under the research, monomials are seen as set term clusters that form a specific term in a relevant terminology of the relevant language. Monomials are differentiated for their structure and syntagmatic relations inter alia. The underlying focus is on the number of terms in the term - monomial, which causes taxonomy of such monomials in relevant terminologies and languages. Where a monomial consists of one term only, it is referred to as a mono-term monomial. Where it is a two-term, three-term or multi-term, the monomials are referred to as a bi-term or multi-term, respectively. Bi-term monomials and multi-term monomials should not be confused with a binomial or a polynomial. The syntactic relation of coordination is of critical value for polynomials in general and binomials, in particular.
\end{abstract}

Key words: monomial, binomial, polynomial, algebraic expression, applied linguistics, terminology.

Introduction. The research into terminologies and inter-disciplinarily related topics go hand in hand. Politics, law, finance, engineering, chemistry, aerospace etc. as specific domains of knowledge are characterized by their relevant symbols and linguistic labels, clearly defined and strictly set concepts in the terminological systems. The study of the term links to the linguistic restrictions including lexical, syntactical and semantic ones, on the one hand, and on the other, it connects to the concept restrictions, i.e. generic, portative and casual. Accounting for these, it becomes possible to differentiate a term from a word, where a term arises as mono-referential in a very specific concept at high degree relating to a specific area or field or discipline, e.g. English for Law, Ukrainian for Agriculture, German for Construction and Real Estate, Portuguese for Hospitality and Cuisine, etc. as terminologies for respective languages. Lynne Bowker defines terminology as a discipline that deals with the collection, processing, description and presentation of terms which are lexical items belonging to a specialized subject field. Going further into literature review, Gumanová (2016) investigates the concept of the analogue rule as a method employed in translatology, while focusing on the term-formation processes employed in the
English and Slovak texts [6]. The author analyses thirty-two randomly selected English and Slovak terms taken from randomly selected EU text in the field of pharmacovigilance in order to investigate how effective the application of the analogue rule can turn out. However, the findings presented may not fully evidence the terminological discrepancy in light of term-formation processes. Valeontis and Mantsari (2006) identify the theory of terminology with three different dimensions: cognitive, linguistic and communicative dimension, according to Sager (1990) [8]. The researchers see the linguistic dimension mainly in the linguistic mechanisms that set the patterns for term formation and term forms, in Greek, particularly. Thus, their key focus is on the presentation of general linguistic principles concerning term formation, during primary naming of an original concept in a source language and secondary term formation in a target language [8].

Aim of the research. With the emphasis on term formation and term forms in any language, taken the findings of the earlier publications [2 - 5], this paper aims to briefly describe monomials in the Ukrainian, English and Portuguese languages as set term clusters for their syntagmatic relations. In Monomial Variables in English Audit Terminology (2019), 
Binomials in English Audit Terminology (2019), Monomials in English for Law (2020), monomials and polynomials are presented as terms of fixed term structure and the findings emphasize the distinct similarities between terms in linguistics and algebraic terms in mathematics $[3 ; 4 ; 5]$. The underlying message links to the terms, components of the term, to be more exact, and interrelation of such terms inside the term, which is a terminological set expression in a language for specific purpose, on the one hand. On the other, the similarity line is drawn to terms and interrelation of such terms in an algebraic expression (its terms/components and operations) [3; 5]. Hence the idea to substitute the term 'term' with a 'monomial' or 'polynomial' for terminology and data mining purposes.

The research objectives determine the following tasks:

(a) To provide examples of Ukrainian, English and Portuguese monomials, i.e. monoterms, bi-terms or multi-terms according to the number of terms in a term,

(b) To define such monoterms, bi-terms or multi-terms in the Ukrainian, English and Portuguese.

The randomly selected monomials make material from the Handbook of International Quality Control, Auditing, Review, Other Assurance, and Related Services Pronouncements (Volume I) validated by the International Auditing and Assurance Standards Board (IAASB) as of 2017 and 2018 [9]. The methodology is built with experimental techniques following the observational research, descriptive method, and the component analysis.

Discussion and results. In Ukrainian for Law and Portuguese for Law as 'Understudied' Languages for Specific Purposes, it is observed that it is generally English for specific purposes, that is widely investigated and discussed among academia [2]. Such languages as Ukrainian, Portuguese, Slovak or Polish gain minor attention if any at all, following the proceedings of international conferences and symposia worldwide [2]. For this reason, the author refers to the mentioned languages and the like as 'understudied' language for geography, historic, political and economic constraints, in particular. Following the 'understudied' aspect, it is also the terminology of audit and accounting, which can hardly boast of much research in languages. Terminologies, or languages for finance, business, economics, IT and law have turned more popular in recent decades. That is why, Ukrainian for Audit and Accounting, English for Audit and Accounting, Portuguese for Audit and Accounting will serve material to exemplify monomials as set term clusters in the field of audit and accounting.

\section{Structure of monomials in the Ukrainian} (UA), English (EN) and Portuguese (Pt) languages. The findings of the research allow for grouping the Ukrainian, English and Portuguese monomials according to the number of terms in their structure. The determinant and identifier to which group the monomials and their equivalents, semiequivalents, quasi-equivalents in respective languages belong is the number of terms in the Ukrainian monomial. Thus, please see the monomials under Group A. These include one term only in their structure in a relevant language: UA аномалія (anomalija), EN anomaly, PT anomalia 'a misstatement or deviation that is demonstrably not representative of misstatements or deviations in a population' [IAASB, 11]; UA помилка (pomylka), EN error, PT erro 'an unintentional misstatement in the financial statements, including the omission of an amount or a disclosure' [IAASB, 20]; UA форма (firma), EN firm, PT empresa 'a sole practitioner, partnership or corporation or other entity of professional accountants. "Firm" should be read as referring to its public sector equivalents where relevant' [IAASB, 21].

Group B includes monomials that are set term clusters and such monomials consist of two terms only in their structure in a relevant language: UA застосовні критерії (zastosovni kryteriji), EN applicable criteria, PT critérios aplicáveis the criteria used by the entity to quantify and report its emissions in the GHG statement' [IAASB, 11]; UA застосовні крumepiï (zastosovni kryteriji), EN applied criteria, PT critérios aplicados 'the criteria applied by management in the preparation of the summary financial statements' [IAASB, 12]; UA спеціальні знання (special'ni znannja), EN expertise, PT expertise 'skills, knowledge and experience in a particular field' [IAASB, 20]; UA суттєвість компонента (suttjevist' komponenta), EN component materiality, PT materialidade do componente 'the materiality for a component determined by the group engagement team' [IAASB, 16]; UA аудиторський фрайл (audytors'kyj fajl), EN audit file, PT ficheiro da auditoria 'one or more folders or other storage media, in physical or electronic form, containing the records that comprise audit documentation for a specific 
engagement' [IAASB, 14]; UA базовий рік (bazovyj rik), EN base year, PT ano-base / ano de referência 'a specific year or an average over multiple years against which an entity's emissions are compared over time' [IAASB, 15]; UA ціль контролю (tsil' kontrolju), EN control objective, PT objectivo de controlo 'the aim or purpose of a particular aspect of controls. Control objectives relate to risks that controls seek to mitigate' [IAASB, 16].

Group $C$ contains monomials that are set term clusters in Ukrainian, English and/or Portuguese and such monomials consist of three or more terms in their structure: UA управлінський персонал групи (upravlins'kyj personal hrupy), EN group management, PT gestão de grupo 'management responsible for the preparation of the group financial statements' [IAASB, 23]; UA ризик завдання 3 надання впевненості (ryzyk zavdannja z nadannja vpevnenosti), EN assurance engagement risk, PT risco de asseguração de garantia 'the risk that the practitioner expresses an inappropriate conclusion when the subject matter information is materially misstated' [IAASB, 14]; UA завдання з надання обмеженої впевненості (zavdannja z nadannja obmezhenoji vpevnenosti), EN limited assurance engagement, PT asseguração de garantia limitada 'an assurance engagement in which the practitioner reduces engagement risk to a level that is acceptable in the circumstances of the engagement but where that risk is greater than for a reasonable assurance engagement as the basis for expressing a conclusion in a form that conveys whether, based on on the procedures performed and evidence obtained, a matter(s) has come to the practitioner's attention to cause the practitioner to believe the subject matter information is materially misstated'; UA завдання з виконання узгоджених процедур (zavdannja z vykonannja uzhodzenykh procedur), EN agreed-upon procedures engagement, PT asseguração de procedimentos acordados 'an engagement in which an auditor is engaged to carry out those procedures of an audit nature to which the auditor and the entity and any appropriate third parties have agreed and to report on factual findings' [IAASB, 10]; UA Міжнародні стандарти фонансової звітності (Mižnarodni standarty finansovoji zvitnosti), EN International Financial Reporting Standards, PT Normas Internacionais de Relato Financeiro 'the International Financial Reporting Standards issued by the International Accounting Standards Board' [IAASB, 24].

Differentiation by structure in definition of monomials in the Ukrainian (UA), English $(\mathrm{EN})$ and Portuguese (Pt) languages. The number of terms in the term - monomial, leads to understanding of certain irreversibility to observe the grammatical patterns, concepts and standards in a relevant language. This, in its turn, causes taxonomy of such monomials in relevant terminologies of the Ukrainian, English and Portuguese languages. Where a monomial consists of one term only, it is referred to as a mono-term monomial, or a mono-term. For example, UA аномалія (anomalija), EN anomaly, PT anomalia, UA формма (firma), EN firm, PT empresa, and other monomials in Group A make mono-term monomials, or monoterms, as the term consists of one term only.

Group B represents another group of monomials. These consist of two terms in the monomial structure, for instance: UA застосовні критерії (zastosovni kryteriji), EN applied criteria, PT critérios aplicados; UA ayдuторський фрайл (audytors'kyj fajl), EN audit file, PT ficheiro da auditoria; UA суттєвість компонента (suttjevist' komponenta), EN component materiality, PT materialidade do component, etc.

Group C displays a number of Ukrainian, English and Portuguese monomials that include more than two terms in the structure: UA завдання з виконання узгоджених процедур (zavdannja z vykonannja uzhodzenykh procedur), EN agreedupon procedures engagement, PT asseguração de procedimentos acordados; UA Міжнародні стандарти ффінансової звітності (Mižnarodni standarty finansovoji zvitnosti), EN International Financial Reporting Standards, PT Normas Internacionais de Relato Financeiro, etc. Where it is a two-term, three-term a term with more than three terms in the structure, the monomials are referred to as a bi-term or multi-term, respectively. Bi-term monomials and multi-term monomials should not be confused with a binomial or a polynomial.

Conclusion. The findings of the research illustrate a wide range of Ukrainian, English and Portuguese monomials as set term clusters in their respective languages. These monomials according to their structure vary from a monoterm monomial to a bi-term monomial or to a multi-term monomial. A mono-term monomial, or a mono-term, stands for a monomial that consists of one term only (Group A above). A bi-term monomial, or a bi-term, has two terms in the structure set in a fixed order abiding by the grammatical and semantic restrictive settings (Group B). A multi-term monomial, or a multiterm, is a monomial that includes more than two terms in the structure and is characterized by a more complex syntactic nature.

It is not always that a mono-term in 
Ukrainian corresponds to a mono-term in English and/or Portuguese and vice versa. Similarly, it is traced with bi-terms or multiterms, e.g. UA спеціальні знання (special'ni

\section{References}

1. Bolondi, G., Ferretti, F., Maffia, A. (2018). Monomials and polynomials: the long march towards a definition. Teaching Mathematics and Its Applications (2018) 00, 1-12.

2. Chaika, O. (2018). Ukrainian for Law and Portuguese for Law as 'Understudied' Languages for Specific Purposes. Philological journal, Vol. 1 (11), pp. 118-127.

3. Chaika, O. (2019). Monomial Variables in English Audit Terminology. International journal of philology. Kyiv: «MILENIUM», Vol. 10 (1). P. 100108.

4. Chaika, O. (2019). Binomials in English Audit Terminology. International Journal of Philology, Vol. 10 (3), Kyiv : «MILENIUM», pp. 6873.

5. Chaika, O., Zakatei, Yu. (2019). Monomials in English for Law, Philological journal, Vol. 2 (14), pp. 114-121.

6. Gumanová, G. (2016). An Analysis of znannja), EN expertise, PT expertise. The mentioned leaves room for further study and more analysis in the subject matter.

Term-Formation Processes as Employed in English and Slovak Versions of the EU Texts in the Concept of Equivalence (A Case Study). URL: https://www.researchgate.net/publication/3133840 66.

7. Malkiel, Yakov. (1968). Essays on Linguistic Themes. University of California Press, 415.

8. Valeontis, K., Mantzari, E. (2006). The Linguistic Dimension of Terminology: Principles and Methods of Term Formation. 1st Athens International Conference on Translation and Interpretation Translation: Between Art and Social Science, 13 -14 October 2006. URL: https://www.researchgate.net/publication/2530249 44

9. International Audit and Assurance Standards, Volume I published by the IAASB International Audit and Assurance Standards Board.$=I A A S B$ as referred to in the publication.

\section{МОНОМИ (МОНОМІАЛИ) ЯК СТАЛІ ТЕРМІНОЛОГІЧНІ СПОЛУКИ У ФАХОВИХ МОВАХ}

\section{О. І. Чайка}

Анотація. Ця стаття тісно пов'язується з апробацією ідеї запровадження термінів «моном» та «поліном» як замінників терміна в лінгвістиці, коли йдеться про терміни у їхній варіативності в фрахових мовах, чи мовах для конкретних цілей, чи мовах особливого призначення, чи термінології. Класифрікація автора (Чайка, 2019) мономів і поліномів підкреслює схожість між термінами (компонентами/елементами) та їхній взаємозв'язок в алгебраїчному виразі (алгебраїчні терміни/компоненти та операції між ними) в математиці та термінами (компонентами / елементами) терміна та їхній взаємозв'язок у терміні в лінгвістиці, який $\epsilon$ усталеним виразом у фрахових мовах, чи термінологіях. У дослідженні мономи розглядаються як сукупність термінів за наявності, що утворюють конкретний термін у відповідній термінології відповідної мови. Мономи, з-поміж іншого, диференціюються за своєю структурою та синтагматичними відношеннями. Матеріалом слугують приклади $в$ українській, англійській та португальській мовах, які за частотністю і варіативністю у використанні в досліджуваних термінологіях фрормують певні результати й висновки. Важливим моментом є кількість термінів у терміні. Так, для монома (одночлена $у$ математиці) характерною особливістю $\epsilon$ варіативність, що обумовлює систематизацію мономів у відповідних термінологіях та мовах. Якщо одночлен складається лише з одного терміна, це - монотерм, або моном-монотерм. Коли йдеться про аналіз двох-, трьох- чи багатокомпонентних мономів, такі мономи формують бітерміни чи політерміни як різновид монома. Бітерміни та політерміни як мономи не слід плутати з поліномом і біномом як найчастотніший за вжитком поліном у фрахових мовах відповідних мов. Синтаксичне відношення при аналізі структури монома й полінома має критичне значення, особливо для поліномів.

Ключові слова: моном (мономіал), біном (біноміал), поліном, монотерм, бітермін, політермін, фрахова мова, термінологія. 